University for Business and Technology in Kosovo

UBT Knowledge Center

UBT International Conference

2017 UBT International Conference

Oct 27th, 4:45 PM - 6:15 PM

\title{
The Economic Explanation of Customer Behavior
}

\author{
Semra Bujari \\ International University of Struga, s.bujari@eust.edu.mk \\ Semra Kerim \\ International University of Struga, s.kerim@eust.edu.mk
}

Follow this and additional works at: https://knowledgecenter.ubt-uni.net/conference

Part of the Business Commons

\section{Recommended Citation}

Bujari, Semra and Kerim, Semra, "The Economic Explanation of Customer Behavior" (2017). UBT International Conference. 237.

https://knowledgecenter.ubt-uni.net/conference/2017/all-events/237

This Event is brought to you for free and open access by the Publication and Journals at UBT Knowledge Center. It has been accepted for inclusion in UBT International Conference by an authorized administrator of UBT Knowledge Center. For more information, please contact knowledge.center@ubt-uni.net. 


\title{
The Economic Explanation of Customer Behavior
}

\author{
Semra Bujari ${ }^{1}$, Semra Kerim ${ }^{2}$ \\ ${ }^{1}$ International University of Struga \\ s.bujari@eust.edu.mk \\ ${ }^{2}$ International University of Struga \\ s.kerim@eust.edu.mk
}

Abstract. The economic explanation of customer behavior in the purchasing process starts from the assumption that buying represents a process of choosing products between different alternatives, even under the influence of rational motives. Economic theory, which has given the consumer economic explanation, assumes that homogeneous buyers are present on the market and they behave in a foreseeable manner. The consumer person is seen as a rational buyer who has general information about the market and tries to maximize the expected value of money, time and spent effort. The customer is determined to purchase those products and services that will bring greater satisfaction by taking the price as one of the most important factors in the decision making process for purchasing. Thus, the customer, based on the information they possess, distinguishes between homogeneous products and decides on the lowest-price. In addition to the price in consumer behavior, other factors such as income and factors as quality, service, promotion etc. However, the explanation of economic theory is mostly oriented towards the product, rather than to the consumer, paying particular attention to price and income.

Keywords: consumer behavior, products, factors, revenue, quality, price.

\section{Introduction}

An important feature of economic theory is that it deals with multiple assumptions about consumer behavior. Among the most important assumptions in consumer behavior is: the rational behavior, preferences, information, budget constraints and unmet needs. 1 The question arises as how many of these assumptions are realistic, whether the consumers behave rationally, are they equally informed, do they have approximately the same financial resources, and so on. Although the assumptions that the data represent a solid foundation in which the contemporary economic theories for consumer behavior are developed. In our analysis of the economic explanations regarding consumer behavior, will be taken into consideration, first of all, the effects of price and income on the behavior of pre-consumer customers, while purchasing and after making the purchase decision, customer choice theory, elasticity of price and of income demand and its impact on consumer decision making.

The theoretical explanation of the economic dimensions of consumer behavior will have a practical application in our research where the price and income will be the subject of analysis as factors influencing consumer decisions in the process of purchasing a products.

\footnotetext{
${ }^{1}$ John C.Mowen, Consumer behavior,2nd edition, The Macmillian Publishing Company, New York, 1990.p.676
} 


\section{The impact of the price and income in the process of customer decision making before purchase, during purchase and after purchase decision}

Due to the clarification and understanding of the economic explanation of consumer behavior in the market for personal consumption, it is necessary to include more economic aspects and factors associated with that problem. The process begins with the act of purchase itself (decisions before purchasing the customer), it continues during the buying time when it is resolved between different brands of products (purchase decisions) and ends with the costumers' behavior after the completion of the purchase process. After the end of the process, consumers are experiencing a degree of satisfaction or dissatisfaction with the purchased product, whether it will buy the same product again or not (after-purchase decisions). In the upcoming parts of this paper work will be given a detailed look at the impact of price and revenue in the decision-making process prior to purchase, during purchase and after the purchase. Price and income as the most important factors represent the basis for the quantitative dimensioning of consumption, or the total purchasing power by which the consumer structure is also determined.

Price is one of the most important criteria for evaluation. Consumer choice often depends on price. The price of products and services as well as the relationship between market prices represent one of the most important factors of demand and consumption. During the non-change of other consumer factors, price changes have the effect of changing consumption, primarily depending on the size of the price change and the newly established price relationships in the market. Price formation, regardless of the cost, takes into account the intentions of the companies, such as gaining profit and, above all, meeting customer needs.

When making purchasing decisions, the customer often decides quickly. For this purpose, he uses the trust he has for a particular company on the market, based on his previous experience, his brand, and the experience and loyalty that he has towards certain brands in the market and the price. The price in this direction is used when it is high and thus shows high quality. This finding will also be verified by the results obtained through research where the brand of children's Pampers, as a brand with high prices and high quality, is at the same time the preferred choice of consumers on the basis of responses provided by the respondents.

When it comes to the price it should be mentioned that it represents the value of the general demand. Price is a factor of particular importance to some customers but not to all of them. So if a consumer does not pay the price that he thinks is too high, it does not mean that the price will decrease in his opinion. Simply this means that other customers are willing to pay that price with the opinion that that price is acceptable to them. Some customers would have paid even more in order to buy the brand product with which they had a positive experience.

The main determinant of the real and potential demand in the market is presented through customer incomes. Consumer incomes and their ability to purchase products make the consumer market of particular interest in terms of our research. In this context of particular importance is the analysis of the available income and the income of the consumers. The customer's disposable income represents the sum of all income from all sources, such as salaries, interest from savings, credit etc. These represent the amount of money available for savings or expense. There is a high level of interdependence of disputable income and personal consumer consumption. Discretionary revenues are part of the available income which remains after the consumer's existential needs have been met. Increasing discretionary revenues affects consumption growth. When deciding on purchases, the question is to decide which brand of products we will buy. It is important to answer the question of which products consumers spend on disposable income. The size of the revenue determines the ability to purchase, as well as the choice of brands for current products in the market. This clearly speaks of the impact of income on consumption and shows the strong link between them. The general economic rule is that with the increase in revenue the purchasing power of the consumer increases and the income is reduced by their 
purchasing ability. While for some products the increase or decrease of income does not affect the change of consumption.

It can be noted that when making purchasing decisions for products on the market for personal consumption, specifically for children's pampers, consumers spend the available income. From the results obtained from the research, consumers classify these products in the required product group. These products are designed for extensive consumption that meets the needs for life. The main feature of these products is the small elasticity in terms of price change, but also in terms of revenue variation. Occasional changes in consumer incomes do not affect the income available for the purchase of pampers.

To clearly see the impacts of price and revenue in the decision-making process for purchasing customers, three stages will be considered: pre-purchase decisions, purchase decisions and postacquisition decisions. It is necessary to emphasize that in this paper special attention is paid to the use of children's pampers who represent themselves as a specific category of products. On the basis of the results obtained from the ongoing research, the impacts of price and income will be considered in the above-mentioned phases.

The first stage is characterized by the need when purchasing customers. Presenting the need, also called the problem review, is one of the central topics in the decision-making process for purchasing. In this paper, this phase begins with the emergence of the need for children, who are of an existential character in the process of growth and development of children. At this level of decision-making for the purchase of children's pampers, parents through researching and gathering information on the offers of child-pampers of a special importance to the brand and quality, while at this stage the impact of the prize and the income are as a second plan as a factor for placement.

The second phase involves the act of acquiring it by choosing an alternative. In this case it is about comparative alternatives that have similar characteristics that can be compared. Often, the choice is the alternative that meets the tire criteria in terms of quality, price, available income and characteristics of the personal product. Even at this stage of revenue impact, it remains unchanged, as far as possible changes in purchase decisions during eventual price changes. Thus, the existence of certain types of consumer packaging and the sale of complementary products emphasize the impact of the price on the decision during the purchase act itself.

The last stage or post-acquisition decisions are related to the degree of customer satisfaction after using the products. While the product meets their requirements and expectations, which are often seen by customer feedback, is brought a decision for further purchase of that product. Under the influence of eventual reduction of income, consumers are oriented towards the choice of existing alternatives, so they choose the alternative with the lowest price. Under these conditions, the use of a new brand of children's pimples will not cause consumers the level of satisfaction they expect. In this case, often the consumers decide for the best for their children and return to the higher price alerts and with higher need to meet.

We can conclude that the impact of price and income in the process before, during and after purchasing customers for these types of products almost have no impact. Consumers do not take as important impacts when they make decisions in potential price and revenue changes, but are oriented towards quality that has a dominant influence on the decision-making process of purchasing decisions.

\section{Theory of choosing customers}

The different situation in which the consumer is in different ways determines its choice. In addition, concrete choice depends on concrete purchase, and the level of customer engagement in the purchasing process is largely determined by the goals for which the buyer buys a particular product or service. The buyer behaves differently when buying products for personal 
consumption because of meeting their personal needs, and buckles when they buy products for someone else. This is confirmed by the research conducted in this paper where we analyze parents as consumers when purchasing pampers for their children.

Today's consumers are faced with a wide range of products, brands, prices, and so on. It is important to note that it is of particular importance for this paper to answer the question: To what extent do consumers give their solution? The choice belongs to those products from which consumers receive maximum value. The theory of consumer choice insists on revealing and explaining factors influencing consumer behavior, why some converters are oriented to a certain brand of a product type, while others prefer the other brand. The contemporary economy believes that the theory of consumer choice comes out of four controversies, which at the same time are shown as the basic elements that explain the behavior of consumers. ${ }^{2}$

First, among the goods and services available, the consumer who has a limited income always chooses the best services that maximize their personal satisfaction.

Second, the taste of consumers enables them to classify and combine different goods again depending on the pleasure they offer.

Third, the customer has a limited income they can spend.

Fourthly, the prices of goods that they can buy are given and well-known.

The first two assumptions are related to the theory of usefulness or satisfaction, while the other two are in the sphere of real economic factors affecting consumer behavior.

The third and fourth element of customer choice theory together defines the budget constraint of consumers. This term describes the different product groups that consumers can use. The budget limitation indicates the limitation that customers decide to give to the income and market prices of the given products. 3

\section{Conclusion}

Consumers during decision making face unlimited choices while their income is limited. In order to make the right choice, consumers must combine budget constraints and preferences (what they want to consume) It can be said that with the limited income of the respondents with given prices of children's pampers, the one that plays an important role in brand selection is taste and preference. Their orientation for the degree of satisfaction and benefit is manifested through the reactions of the children as the primary user who will gain after using this type of product. Satisfaction and usefulness will be at the maximum level only when quality as a key feature of this product will comply with budget constraints as a choice that represents the optimal or ideal combination for the chosen childrens pampers. For the theory of consumer choice we can conclude that it explains how consumers choose what they want to do, as described by their taste and preferences, and what the market will allow them to do, as described in income and product prices. The choice theory enables us to predict how consumers will react to changes in market conditions. It helps us understand the price and revenue elasticities that will be the subject of our analysis in the coming part4.

\footnotetext{
2 Таки Фити, Владимир Филиповски, “Основи на микроекономија” , 1999 стр.65

${ }^{4}$ Begg.D.K.H.,Fischer, S., Dombusch R., “Economics”, McGraw Hill, 2000 p.71
} 


\section{References}

1. A.H.Maslow:"Motivation and personality", $3^{\text {rd }}$ edition. New York:Harper\&Row,latest edition

2. D.Hawinks, R.Best,K.Coney:"Consumer Behavior, Implications for marketing strategy",Six edition, Boston, Richard D.Irwin, INC 1995

3. D.Hawinks,R.Best,K.Coney:"Consumer Behavior,Implications for Marketing strategy", Richard D Irwin, INC 1992

4. Јаќоски Бошко “Маркетинг” Економски Факултет, Скопје, 1991

5. Јаќоски Бошко “Маркетинг- основи на теоријата и примената”, Студентски збор, Скопје, 1991

6. J.Alba, J Lunch, B.Weitz, C.Janasqevski, R.Lutz,A.Sawer and S.Wood, "Interactive Home shopping: Consumer, Retailer and Manugacturer Incetives to Participate in Electronic Marketplaces”, Jurnal of Marketing,61(July1997)

7. John C. MOwen:"Consumer behavior" second edition, MasMilan Publishing Company, New York, 1990

8. John O'Shanghessy:"Competitive Marketing: A.Strategic Approach, George Allen and Unwin, Boston, 1984

9. James F.Engel-Roder D.Blackwell- Paul W.Miniard,"Consumer behavior",six edition, The Dryden Press, Chicago, 1990

a. Begg.D.K.H.,Fischer, S., Dombusch R., "Economics”, McGraw Hill, 2000

10. Kotler Philip,"Marketing”, Simon-Shaster Inc, London, 1999

11. Kotler Philip,'Marketing Management", $11^{\text {th }}$ edition, Pretice Hall-2003

12. Kotler Philip,Armstrong Garry,"Principles of Marketing", $7^{\text {th }}$ edition Prentice Hall, 1996

13. Таки Фити, Владимир Филиповски, “Основи на микроекономија”, 1999

14. Leon g.Schiffman-Leslie Lazar Kannuk,:Consumer Behavior, second edition, PrenticeHall, Inc, Engelwood Cliffs, New York, 1983

15. L.Schiffman, L.Kanuk:"Consumer behavior", $9^{\text {th }}$ edition, pretice hall, Inc, Engleswood Cliffs, New York,2007

16. B.Maricic :" Ponasanje potrošača", Savremena administracija, Beograd,1993

17. B.Maricic:" Ponasanje potrošača:marketinski pristup", Ekonomski fakultet, Beograd, 1991

18. Bazala d-rA.:,Istraživanje tržišta- metode i područja delovanja ", velebit-Velegraf, Zagreb, 1991

19. Башеска -Ѓорѓиеска М, Секуловска Н:”Маркетинг ИСтражување- информативен инпут на маркетинг менаџментит ”, Киро Дандаро, Битола, 1998

20. Бојаџиоски Д, Блажеска О :"Економика на претприатие”, Економски Факултет, Скопје 2003 